\title{
Imaging with non-FDG PET tracers: outlook for current clinical applications
}

\author{
Egesta Lopci • Cristina Nanni • Paolo Castellucci • Gian Carlo Montini • \\ Vincenzo Allegri • Domenico Rubello • Franca Chierichetti - Valentina Ambrosini • \\ Stefano Fanti
}

Received: 29 April 2010 /Revised: 17 July 2010 /Accepted: 9 September 2010 /Published online: 23 September 2010

(C) European Society of Radiology 2010

\begin{abstract}
Apart from the historical and clinical relevance of positron emission tomography (PET) with $18 \mathrm{~F}$ fluorodeoxyglucose (18F-FDG), various other new tracers are gaining a remarkable place in functional imaging. Their contribution to clinical decision-making is irreplaceable in several disciplines. In this brief review we aimed to describe the main non-FDG PET tracers based on their clinical relevance and application for patient care.
\end{abstract}

Keywords Positron emission tomography · Hybrid PET/ CT . Functional imaging $\cdot$ PET tracers $\cdot$ Non-FDG

E. Lopci · C. Nanni · P. Castellucci · G. C. Montini · V. Allegri · V. Ambrosini $\cdot$ S. Fanti

PET Unit, Nuclear Medicine Department,

University Hospital Sant'Orsola-Malpighi,

Bologna, Italy

D. Rubello

Nuclear Medicine Service, PET Unit,

Hospital Santa Maria della Misericordia (IOV),

Rovigo, Italy

F. Chierichetti

Nuclear Medicine Service, PET Unit, Hospital San Giacomo,

Castelfranco Veneto, Italy

E. Lopci $(\bowtie)$

Department of Nuclear Medicine,

University Hospital S.Orsola-Malpighi,

Via Massarenti, 9,

CAP 40138 Bologna, Italy

e-mail: egesta_lopci@excite.it

\section{Introduction}

The introduction of molecular imaging and the recent development of hybrid systems, in which both functional and morphological information are acquired simultaneously and can therefore be registered accurately, has led to a great step forward in diagnostic imaging. Positron emission tomography (PET) has paved the way for the introduction of PET/computed tomography (CT). These machines have been available since the last decade of the twentieth century [1], and PET/magnetic resonance imaging (MRI) machines are likely to be available in the near future.

Currently, 18F-fluorodeoxyglucose (18F-FDG) represents the prevailing tracer utilised in PET imaging. For this tracer oncology is undoubtedly the most important field of application, but other clinical fields in which 18F-FDG plays an important role include neurology and cardiology.

The main disadvantage of $18 \mathrm{~F}-\mathrm{FDG}$ is that it is not a specific oncological tracer, as several malignancies [i.e. prostate cancer, hepatocellular carcinoma (HCC), renal cell carcinoma, etc.] cannot be adequately assessed by $18 \mathrm{~F}$ FDG-PET. Therefore other new radiopharmaceuticals have been developed that are capable of giving more specific information, leading to a better sensitivity and specificity or just complementing 18F-FDG-PET results (Fig. 1).

At present a very wide variety of non-FDG-PET tracers have been studied. Some of them are already used in clinical practice, while others are still undergoing investigation in clinical and preclinical trials. In this paper, we will focus on some of them by selecting the principal non-FDGPET tracers on the basis of their clinical relevance and application (Table 1). 
Fig. 1 Maximum intensity projection (MIP) images of six different PET tracers and their normal distribution: (a) 18Ffluorodeoxyglucose (18F-FDG); (b) 11C-choline; (c) 11Cmethionine; (d 18F-dihydroxyphenylalanine (18F-DOPA); (e) 68Ga-DOTA-1-NaI3-octreotide (68Ga-DOTA-NOC); (f) 11Cacetate

\section{Iconography}

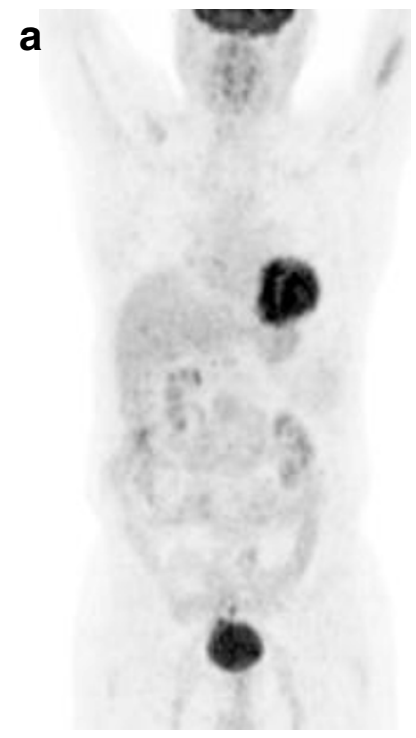

b

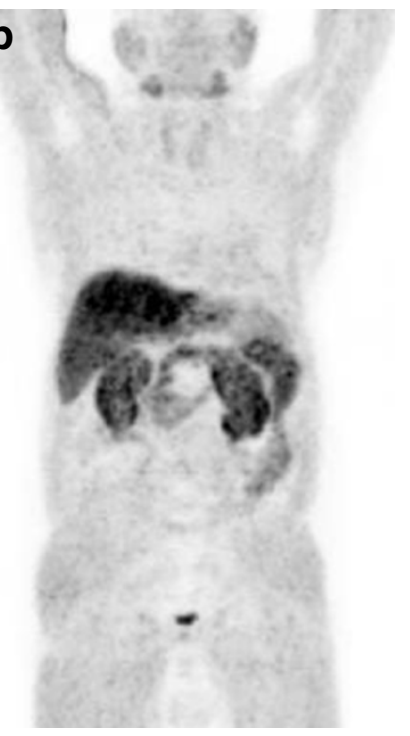

MIP images

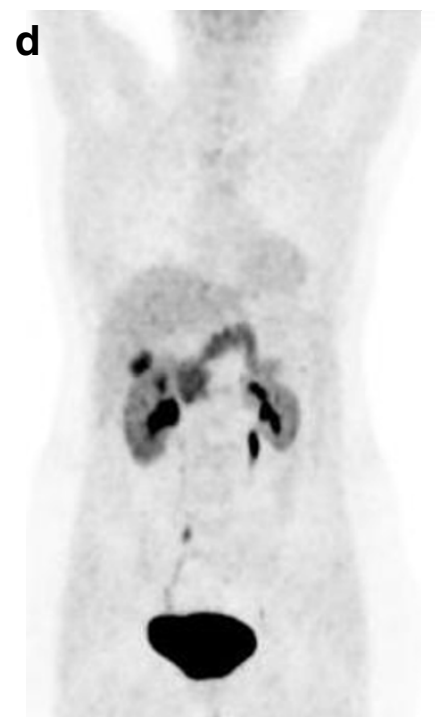

e

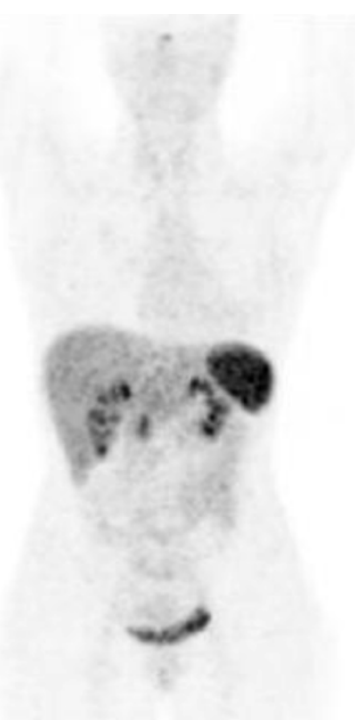

C

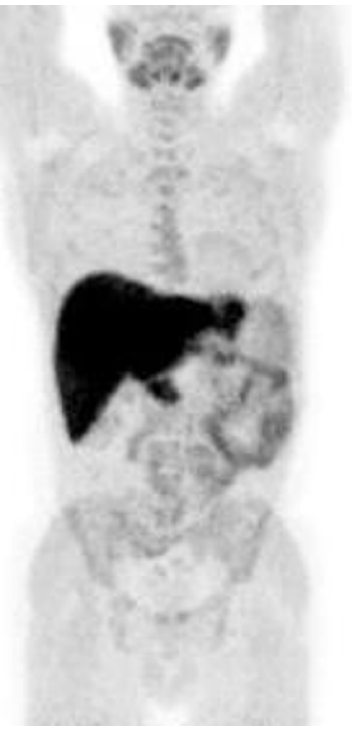

\section{f}

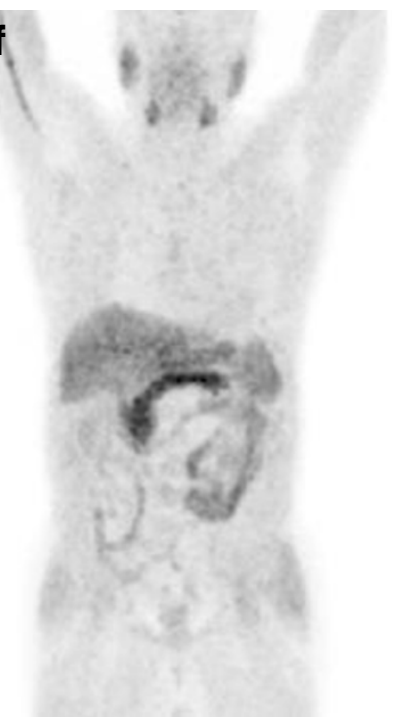

\section{Choline metabolism}

\section{(11C-choline)}

11C-Choline and its fluorinated analogue (18F-fluorocholine), as precursors for the biosynthesis of cellular membrane phospholipids (i.e. phosphatidylcholine), represent specific PET tracers capable of marking out membrane metabolism and turnover. These processes are both known to be increased in tumour cells [2]. The two tracers show no significant difference in diagnostic performance and biodistribution, except for the earlier urinary appearance of $18 \mathrm{~F}$-choline, probably due to an incomplete tubular reabsorption [3].
For many tumour types, choline-PET is reported to be a good diagnostic technique, although in practice its clinical value is mainly limited to prostate cancer [4].

For staging purposes, $11 \mathrm{C}$-choline has been utilised in selected high-risk patients (high levels of PSA or Gleason score), with the intent to assess extra-prostatic nodal and bone metastases. For N- and M-staging, 11C-choline-PET performs better than clinical nomograms [5]: it has a patient-based sensitivity and specificity of $60.0 \%$ and $97.6 \%$ respectively, and a nodal-based sensitivity and specificity of $41.4 \%$ and $99.8 \%$ respectively [6], whereas, for staging of the primary prostate cancer (T-staging), choline-PET is not suitable [6-8]. 
Table 1 Main non-FDG-PET tracers and their principal indications

\begin{tabular}{|c|c|c|c|c|}
\hline Tracer & $\begin{array}{l}\text { Metabolic } \\
\text { process }\end{array}$ & $\begin{array}{l}\text { Diagnostic } \\
\text { imaging }\end{array}$ & $\begin{array}{l}\text { Oncological } \\
\text { indications }\end{array}$ & Clinical value \\
\hline 11C-Choline & $\begin{array}{l}\text { Cellular membrane } \\
\text { turnover }\end{array}$ & Prostate cancer & $\begin{array}{l}\text { Diagnosis/Biopsy } \\
\text { guidance }\end{array}$ & $\begin{array}{l}\text { Identification of carcinoma foci in } \\
\text { patients with multiple negative biopsies }\end{array}$ \\
\hline \multirow[t]{3}{*}{$\begin{array}{l}\text { 18F-Choline } \\
\text { (FCH) }\end{array}$} & \multirow[t]{3}{*}{$\begin{array}{l}\text { Phosphatidylcholine } \\
\text { metabolism }\end{array}$} & Other tumours: & Staging & $\begin{array}{l}\text { Assessment of proper disease extent in } \\
\text { high-risk patients }\end{array}$ \\
\hline & & Bladder cancer & Suspect of relapse & $\begin{array}{l}\text { Early detection of relapse in patients with } \\
\text { biochemical failure }\end{array}$ \\
\hline & & Brain tumours, etc. & Restaging & $\begin{array}{l}\text { Therapeutic management in patients with } \\
\text { documented carcinoma relapse }\end{array}$ \\
\hline \multirow[t]{5}{*}{ 11C-Methionine } & \multirow[t]{5}{*}{$\begin{array}{l}\text { Amino acid } \\
\text { transport } \\
\text { and protein synthesis }\end{array}$} & Brain tumours & Diagnosis & $\begin{array}{l}\text { Differential diagnosis between benign and } \\
\text { malignant lesions/Inconclusive CIT }\end{array}$ \\
\hline & & Other tumours: & Grading & $\begin{array}{l}\text { Direct correlation between 11C-methionine } \\
\text { uptake and tumour grading }\end{array}$ \\
\hline & & Head and neck, etc. & Stereotactic biopsy & $\begin{array}{l}\text { Detection of more suitable sites for brain } \\
\text { biopsy }\end{array}$ \\
\hline & & Non-oncologic indication: & $\begin{array}{l}\text { Treatment } \\
\text { response/ } \\
\text { Prognostic value }\end{array}$ & $\begin{array}{l}\text { Assessment of treatment efficacy/Direct } \\
\text { correlation between uptake decline and } \\
\text { patient outcome }\end{array}$ \\
\hline & & Hyperparathyroidism & $\begin{array}{l}\text { Suspect of relapse } \\
\text { or residual disease }\end{array}$ & $\begin{array}{l}\text { Characterisation of suspect or inconclusive } \\
\text { lesions at CIT }\end{array}$ \\
\hline \multirow[t]{3}{*}{ 18F-DOPA } & \multirow[t]{3}{*}{$\begin{array}{l}\text { Dopamine uptake } \\
\text { and metabolism }\end{array}$} & $\begin{array}{l}\text { Neuroendocrine tumours } \\
\text { (NET) }\end{array}$ & $\begin{array}{l}\text { Diagnosis/ } \\
\text { Unknown primary }\end{array}$ & $\begin{array}{l}\text { Diagnosis of NET/Documented NET } \\
\text { metastasis in unknown primary }\end{array}$ \\
\hline & & Non-oncological indications: & Staging/restaging & $\begin{array}{l}\text { Assessment of disease extent before } \\
\text { treatment }\end{array}$ \\
\hline & & $\begin{array}{l}\text { Congenital hyperinsulinism } \\
\text { Parkinson }\end{array}$ & Suspect of relapse & Early identification of relapse \\
\hline \multirow[t]{5}{*}{$\begin{array}{l}\text { 68Ga-DOTA- } \\
\text { peptides }\end{array}$} & \multirow[t]{5}{*}{$\begin{array}{l}\text { Somatostatin } \\
\text { receptors }\end{array}$} & $\begin{array}{l}\text { Neuroendocrine tumours } \\
\text { (NET) }\end{array}$ & Diagnosis & Diagnosis of NET \\
\hline & & Other tumours: & Unknown primary & $\begin{array}{l}\text { Identification of primary tumour in } \\
\text { patients with documented NET metastasis }\end{array}$ \\
\hline & & Pheochromocytoma & Staging/restaging & $\begin{array}{l}\text { Assessment of disease extent before } \\
\text { treatment }\end{array}$ \\
\hline & & Paraganglioma & Suspect of relapse & Early identification of relapse \\
\hline & & Microcytoma & Treatment response & Assessment of treatment efficacy \\
\hline \multirow[t]{4}{*}{ 11C-Acetate } & \multirow{4}{*}{$\begin{array}{l}\text { Lipid synthesis and } \\
\text { energetic metabolism }\end{array}$} & Prostate cancer & \multicolumn{2}{|c|}{ Similar to $11 \mathrm{C}$-choline indications for prostate cancer } \\
\hline & & $\mathrm{HCC}$ & Diagnosis of $\mathrm{HCC}$ & $\begin{array}{l}\text { Differential diagnosis between } \\
\text { benign and malignant hepatic lesions }\end{array}$ \\
\hline & & Non-oncological indications: & $\begin{array}{l}\text { Staging/restaging } \\
\text { HCC }\end{array}$ & Assessment of disease extent \\
\hline & & Myocardial metabolism & $\begin{array}{l}\text { Suspect of relapsed } \\
\text { HCC }\end{array}$ & $\begin{array}{l}\text { Characterisation of suspect or } \\
\text { inconclusive lesions at CIT }\end{array}$ \\
\hline $18 \mathrm{~F}-\mathrm{FLT}$ & $\begin{array}{l}\text { Cellular proliferation } \\
\text { and }\end{array}$ & Lymphoma & $\begin{array}{l}\text { Diagnosis/ } \\
\text { Primary } \\
\text { tumour }\end{array}$ & $\begin{array}{l}\text { Differential diagnosis between benign } \\
\text { and malignant lesions/T staging }\end{array}$ \\
\hline \multirow[t]{3}{*}{$\begin{array}{l}\text { TK-1 } \\
\text { activity }\end{array}$} & & Lung & $\begin{array}{l}\text { Treatment } \\
\text { response } \\
\text { evaluation }\end{array}$ & $\begin{array}{l}\text { Treatment response assessed with } \\
\text { FLT-PET correlates with pathological } \\
\text { response }\end{array}$ \\
\hline & & Colorectal cancer & & \\
\hline & & Gastric and pancreatic & & \\
\hline \multirow[t]{2}{*}{$18-\mathrm{NaF}$} & \multirow[t]{2}{*}{ Bone metabolism } & Bone metastasis & Diagnosis & Identification of bone metastasis \\
\hline & & Non-oncological indications: & Staging & $\begin{array}{l}\text { Detection of bone involvement in } \\
\text { tumours with elevated risk of bone } \\
\text { metastasis }\end{array}$ \\
\hline
\end{tabular}


Table 1 (continued)

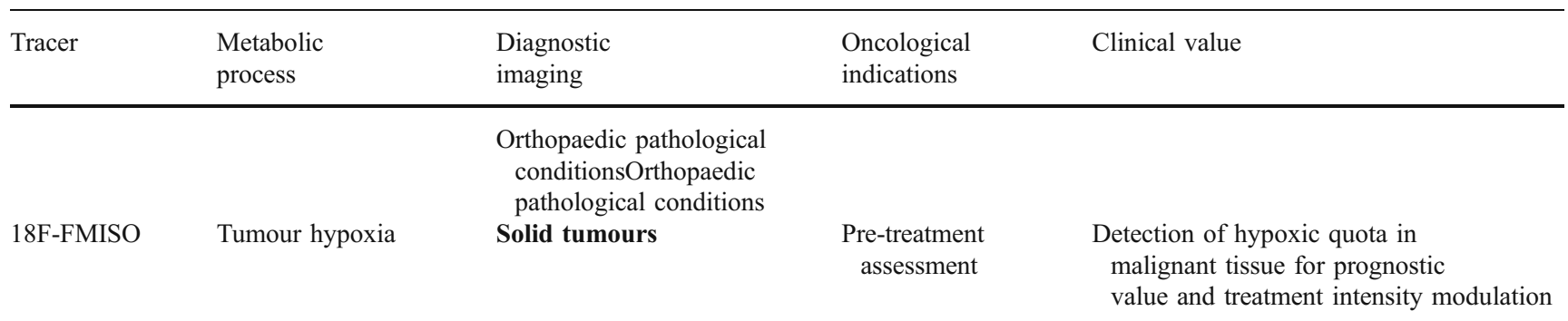

18F-FAZA

$18 \mathrm{~F}-\mathrm{EF} 3$ and 5

64Cu-ATSM

CIT conventional imaging technique

$H C C$ hepatocellular carcinoma

The main indication for using choline-PET remains the evaluation of prostate cancer relapse in previously treated (radical prostatectomy or external beam radiotherapy) patients, who present with a rising PSA serum level [9]. PET performance in this case is reported to be superior to other conventional imaging techniques (CIT) leading to early identification of both nodal and extranodal lesions, as well as local recurrence (Fig. 2) [10-13].

The detection rate of choline-PET, however, can still be low during restaging, especially for low PSA values [12]; therefore, PSA kinetics has been studied. Utilising trigger PSA, PSA velocity and PSA doubling time [9, 14], increases the performance of the method significantly and gives clinicians useful information for a better assessment of treatment strategies and patient follow-up.

Malignancies other than prostate cancer have been studied with choline-PET, such as bladder cancer, brain tumours and multiple myeloma $[4,15]$. The late urinary excretion, characterising $11 \mathrm{C}$-choline, and the low background activity in the pelvic area are the main reasons for the successful use of choline-PET in bladder cancer [4]. In the other tumours, such as brain neoplasia or multiple myeloma, the utility is still questioned and there does not seem to be much improvement in diagnostic accuracy compared with other PET tracers, such as 11C-methionine for brain tumours and 18F-FDG for multiple myeloma [15].

\section{Amino acid and protein metabolism}

\section{(11C-methionine)}

Methionine is an essential amino acid and the uptake of its carbon-11 labelled form (11C-methionine) directly reflects amino acid transport and protein metabolism. These processes are known to be significantly increased in malignant cells as a consequence of the increased cellular proliferation activity [16].

The imaging potentialities of $11 \mathrm{C}$-methionine as an oncological PET tracer have already been documented in different malignancies like brain tumours, breast cancer and head and neck tumours [17-19].

11C-Methionine has a main advantage in brain imaging compared with 18F-FDG: there is almost no tracer uptake in normal brain tissue. On the other hand, malignant lesions show a significantly increased uptake of 11C-methionine, with an optimal tumour-to-background ratio. Also, other benign conditions, such as fibrosis, necrosis or oedema, which usually reduce FDG-PET specificity, show a relatively low uptake with methionine-PET. For these reasons, methionine-PET is predominantly used for the detection of brain tumours [20].

The good correlation that has been reported among the Ki-67 index, proliferating cell nuclear antigen expression and methionine uptake is used to give preliminary information on tumour grading (low- versus high-grade lesions) and provide a reliable initial prognostic value [21-23].

In gliomas, methionine-PET is reported to have good sensitivity and specificity, $89 \%$ and $100 \%$ respectively, and this can determine a change in treatment management in up to $50 \%$ of the cases. However, during acute inflammation and in low-grade forms the diagnostic performance can be suboptimal (sensitivity range 65-85\%) [24, 25].

The good diagnostic performance of methionine-PET is mostly maintained in the case of post-treatment evaluation and during follow-up, when tumour recurrence is suspected [26]: sensitivity, specificity in detecting tumour recurrence range from 77.8 to $100 \%$ and $60 \%$ to $100 \%$, respectively [26]. In recurrent disease, methionine-PET has a major advantage over conventional imaging techniques (including MRI) as it can make a proper differential diagnosis between malignant lesions and other non-pathological findings (i.e. 
Fig. 2 11C-Choline PET in a patient with biochemical failure after radical prostatectomy: MIP and transaxial images document both lymph nodal (arrows) and bone relapse (arrowhead)
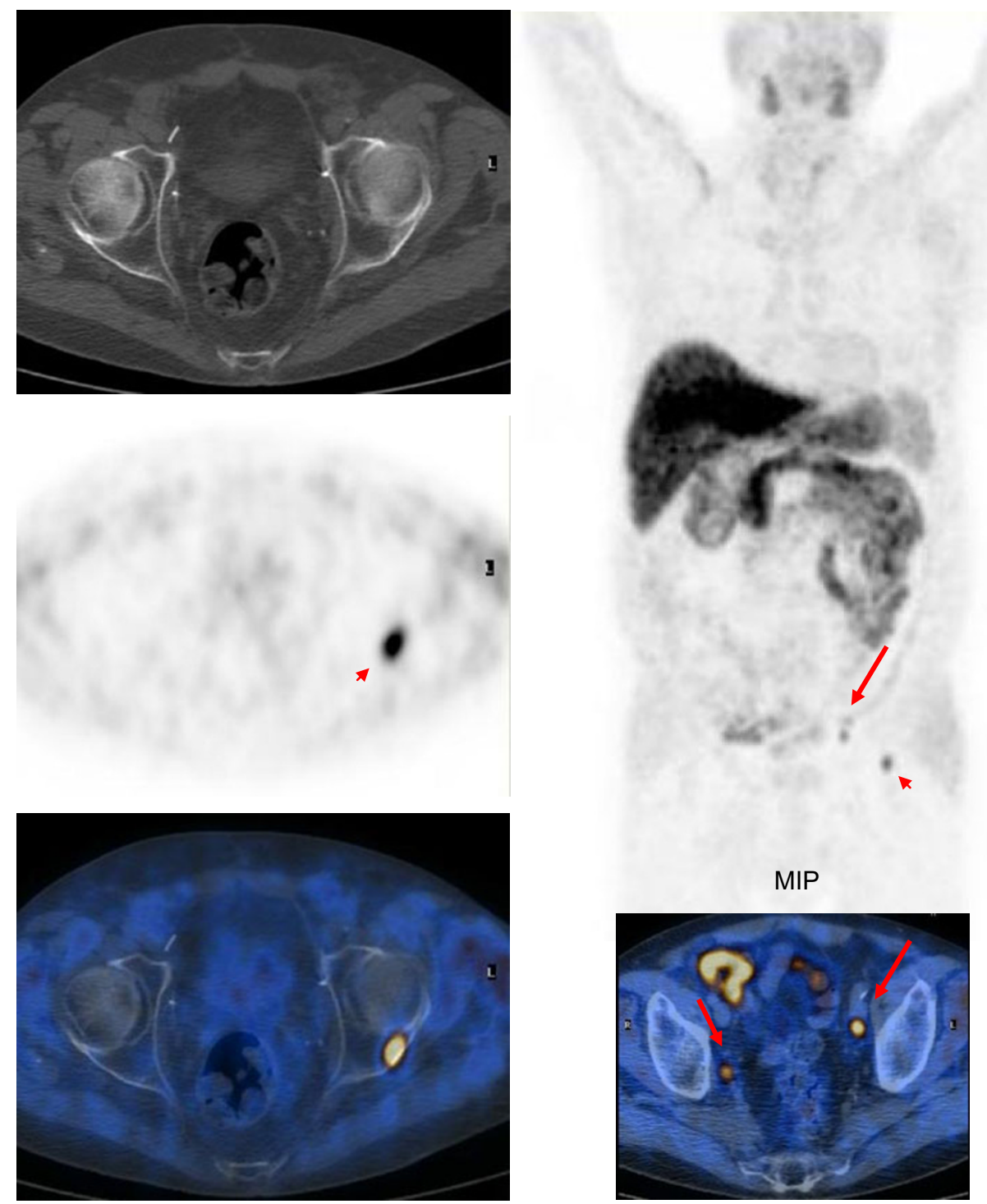

Transaxial images

infection, infarction and haemorrhage) or other brain tissue changes induced by previous surgical handling or external beam radiotherapy (Fig. 3) [23, 27].

The ability of methionine-PET to distinguish accurately between malignant tissue and necrotic areas, combined with the better delineation of tumour volumes, has found a proper use for radiotherapy planning and can be of help for stereotactic brain biopsy too [28].

\section{Dopamine uptake and metabolism}

\section{(18F-DOPA)}

18F-Dihydroxyphenylalanine (18F-DOPA) was first introduced as a marker for imaging dopamine uptake and metabolism in basal ganglia [29]. Afterwards, this tracer was applied for the detection of malignancies such as brain tumours [30], neural crest derived (neuroendocrine) neoplasms [31], and other conditions like congenital hyperinsulinism [32].

The rationale for imaging neuroendocrine with 18FDOPA PET is the ability of these tumours to accumulate and decarboxylate L-DOPA as a precursor of dopamine in the catecholamine pathway [33]. The increased L-DOPA transport within the cells by the large amino acid transporter system (LAT) and the increased activity of LDOPA decarboxylase (AADC) documented in neuroendocrine tumours (NET) [34], the high signal-to-background ratio and the good spatial resolution of the PET camera system, permit the detection of both primary and metastatic lesions in many neuroendocrine malignancies. Examples for which 18F-DOPA PET imaging has proved to be successful are carcinoids, gastro-entero-pancreatic neuroen- 
Fig. 3 11C-Methionine PET in two different patients previously operated on for glioma: (a) residual disease at the level of the surgical crater; (b) glioma recurrence in the contralateral brain hemisphere a
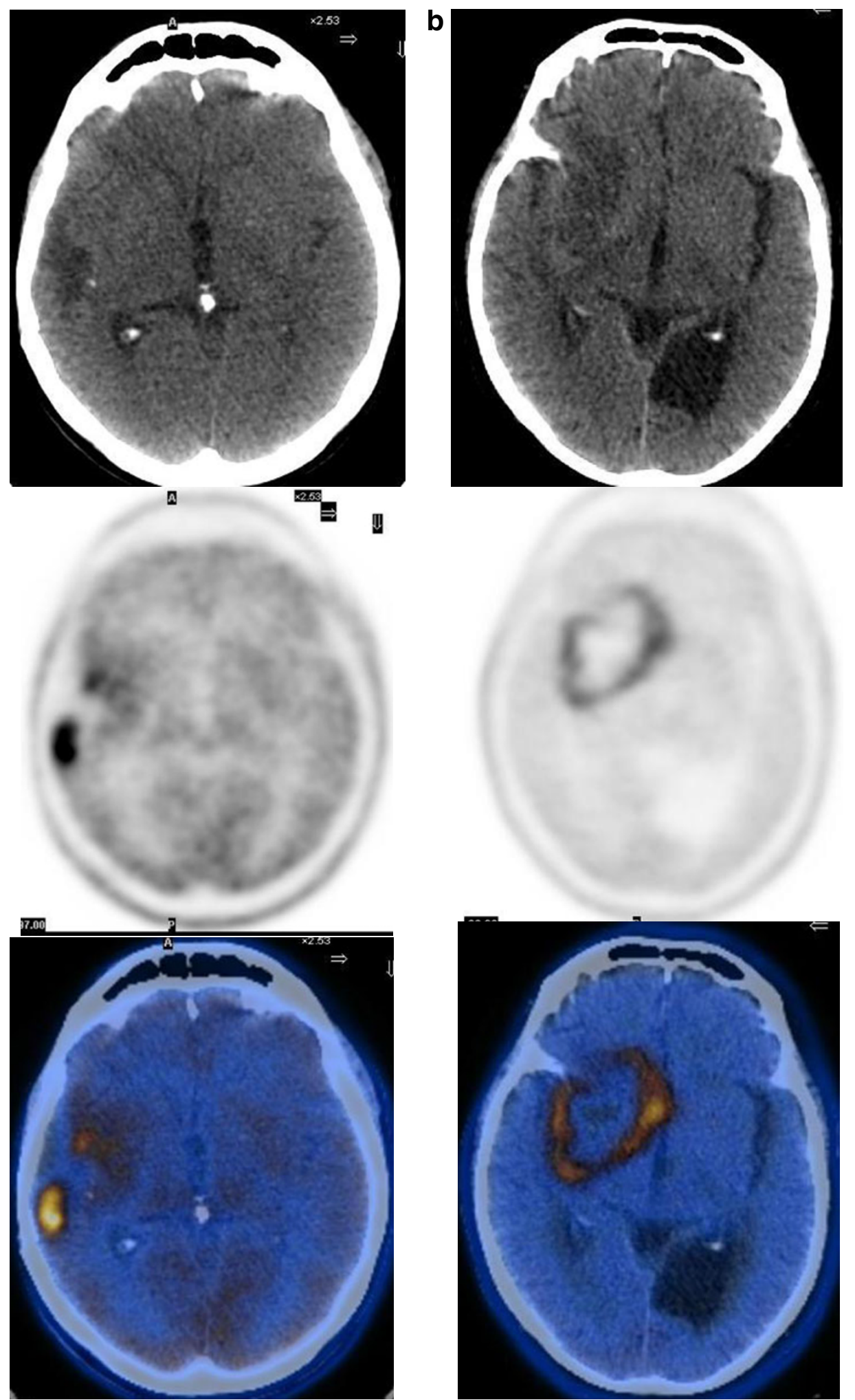

docrine tumours, glomus tumour, medullary thyroid, neuroblastoma, paraganglioma (glomus tumour) and phaeochromocytoma. [31, 35-37].

In neuroendocrine tumours with elevated catecholamine release, such as phaeochromocytomas, 18F-DOPA PET shows the best performance, with sensitivity and specificity rates of $84.6 \%$ and $100 \%$ respectively (Fig. 4) [36]. Moreover, its diagnostic accuracy for the detection of carcinoids [31, 37] and phaeochromocytoma [31, 36] was shown to be higher than that of other imaging techniques, 
Fig. 4 18F-DOPA PET in a patient affected by pheochromocytoma of the right adrenal gland (arrow); physiological uptake of the tracer in the gallbladder (arrowhead)
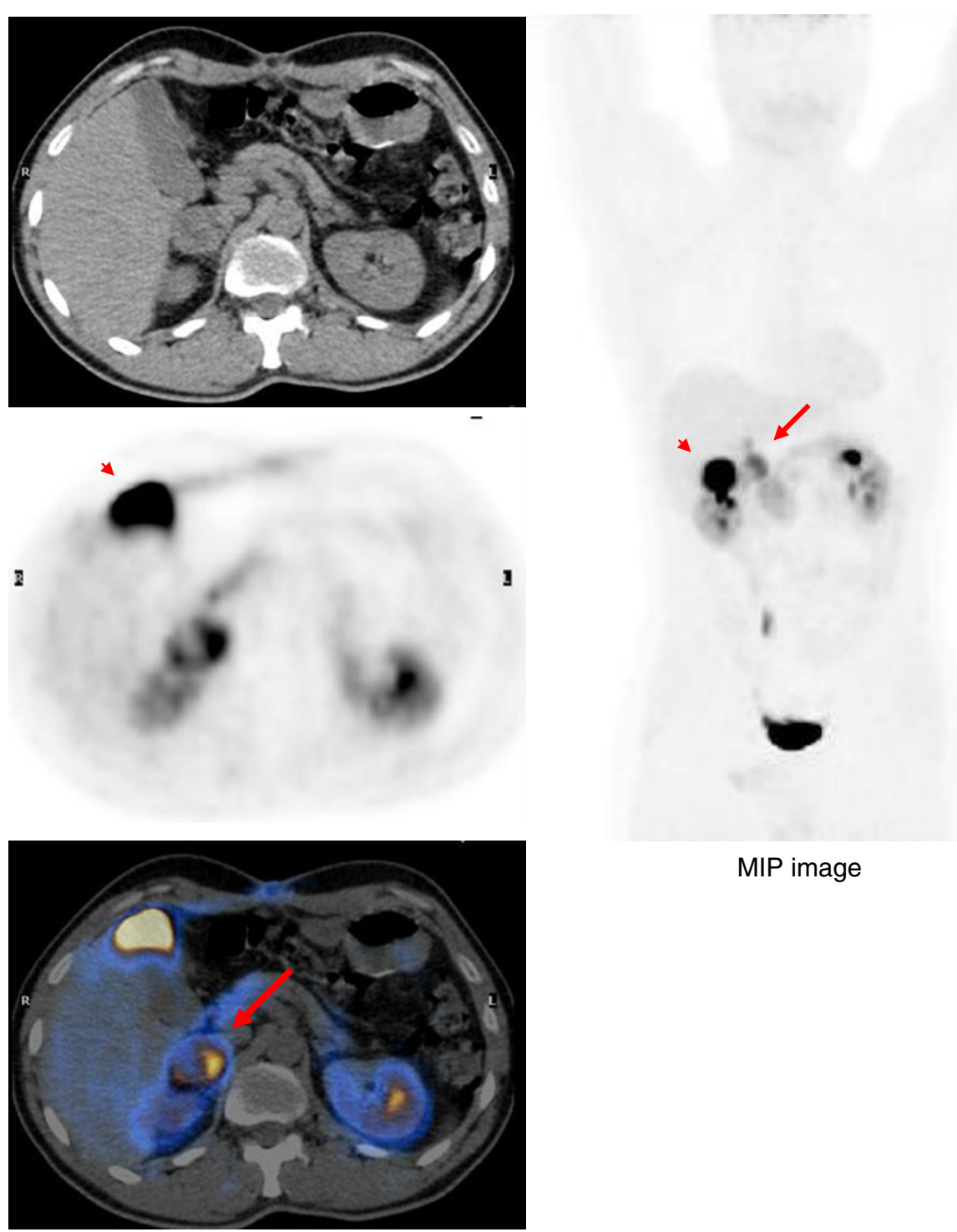

MIP image

Transaxial images

both morphological (including CT/MRI) and functional (123I-MIBG and 111In-Octreoscan) [31, 38].

\section{Somatostatin receptors}

(68Ga-DOTA-NOC and other analogues)

An important characteristic of neuroendocrine tumours is the expression of somatostatin receptors on their cell membrane. Thus far, five somatostatin receptor subtypes have been discovered: SSTR1-5. The SSTR2, SSTR3 and SSTR5 subtypes in particular [39] are often overexpressed on the cell membranes of neuroendocrine tumours (on average in $80-90 \%$ of cases).

The discovery of the overexpression of the somatostatin receptors in neuroendocrine tumours led to the develop- ment of radiolabelled somatostatin analogues. For decades, 111 In-octreotide (Octreoscan) has been considered the "gold standard" for imaging and staging neuroendocrine tumours [40], but recently new PET tracers have been developed for imaging somatostatin receptors in NETs. These radiopharmaceuticals carry a somatostatin analogue labelled with the positron emitting radionuclide $68 \mathrm{Ga}$, which is easily obtainable by a portable $68 \mathrm{Ge} / 68 \mathrm{Ga}$ generator.

In 2001, the first 68Ga-DOTA somatostatin analogues were developed for clinical purposes [41] and up to now several 68Ga-DOTA-peptides have been reported. The majority show a similar affinity for SSTR2 and 5, whereas 68Ga-DOTA-NOC has also demonstrated a high affinity for SSTR3 [42, 43].

In the literature, 68Ga-DOTA-peptides are reported to be excellent candidates for imaging and staging patients with 
neuroendocrine tumours, including the localisation of primary tumours in patients with known NET metastasis (carcinoma of unknown primary origin) (Fig. 5) [44, 45]. Sensitivity and specificity are documented as $97-100 \%$ and $96-100 \%$ in different papers $[46,47]$ and in a large series the diagnostic accuracy was reported to be higher than that of CT, 111In-octreotide or other PET tracers, such as $18 \mathrm{~F}$ DOPA [46, 48, 49]. PET with 68Ga-DOTA-peptides gave additional information to other instrumental investigations in $21.4 \%$ of the cases and led to a change in therapeutic management in $14 \%$ of cases [46, 47].

In addition, PET with 68Ga-DOTA-peptides gives useful information on therapeutic work-up, by providing clinicians with important pre- and post-therapeutic data on tracer uptake and receptor expression. 68Ga-DOTApeptide uptake value (SUVmax) has been demonstrated to correlate with clinical and pathological features in NET, by also resulting in an accurate prognostic factor for patient outcome [50]. As already reported by Gabriel et al. [46, 51], it also gives a preliminary estimation of receptor expression, thus permitting selection of patient candidates for peptide receptor radionuclide therapy (PRRT) and selection of which therapeutic agent to use (90Y-DOTATOC or 177Lu-DOTATATE).

\section{Lipid synthesis and energetic metabolism}

\section{(11C-acetate)}

$11 \mathrm{C}$-Acetate is a two-way tracer that can physiologically cover two different metabolic pathways: one is the pathway

Fig. 5 68Ga-DOTA-NOC PET in a patient with local recurrence of NET after distal pancreasectomy and splenectomy (arrow and arrowhead)
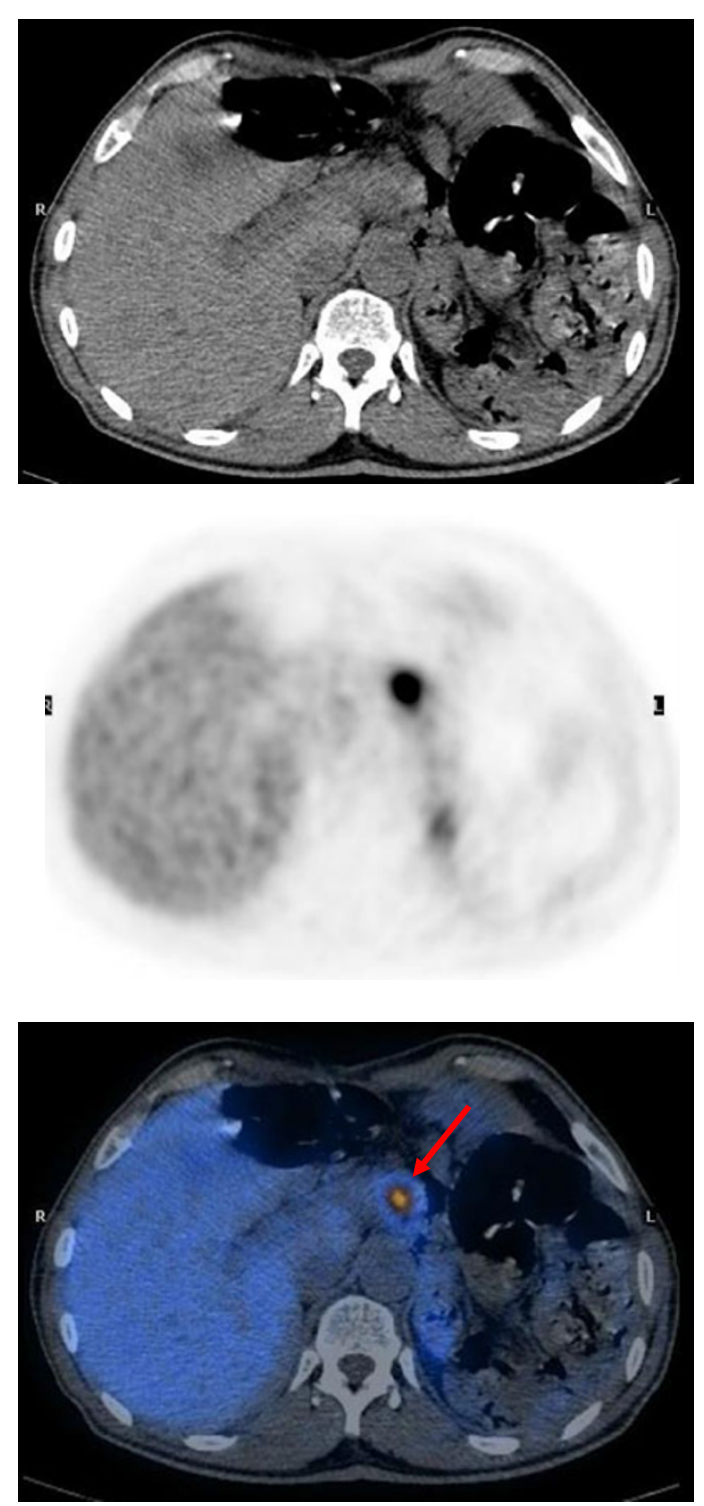

MIP image

Transaxial images 
leading to the synthesis of cholesterol and fatty acids, which are then incorporated into cellular membrane [52], the other one involves energy metabolism via the tricarboxylic acid (TCA) cycle, used either for catabolic or anabolic purposes [53].

The energy pathway was the first one to be utilised for PET imaging with 11C-acetate, and consisted of cardiac studies on the assessment of myocardial blood flow and oxidative metabolism [54]. More recently, acetate-PET has been used in oncology too, for the assessment of some tumours, such as prostate cancer, renal cell carcinoma or HCC, in which FDG-PET is of limited use [55-57]. In those tumours, there is an increased uptake of $11 \mathrm{C}$-acetate related to the over-expression of fatty acid synthetase, a key enzyme that entraps $11 \mathrm{C}$-acetyl-CoA within different cellular structures and pathways [58].

In clinical practice, acetate-PET has a major application in imaging prostate cancer and HCC $[55,56]$.

In prostate cancer, $11 \mathrm{C}$-acetate PET has similar indications to choline-PET and up to now no significant difference in diagnostic accuracy has been found between the two tracers [59]. Acetate-PET can be used from the diagnosis to staging/restaging of prostate cancer [60,61], with major indications in previously treated patients presenting with biochemical failure [55, 62].

11C-Acetate has also found a proper application in the detection of HCC, which usually shows a low FDG uptake, secondary to the lower glycosidic metabolism of tumoral cells, compared with normal liver parenchyma [56, 63].
Acetate-PET has demonstrated a good sensitivity (83$87.3 \%$ ) in the detection of HCC, especially in welldifferentiated forms (Fig. 6) [63]. FDG-PET maintains a role in dedifferentiated HCC, but overall accuracy ameliorates when associating $18 \mathrm{~F}-\mathrm{FDG}$ and $11 \mathrm{C}$-acetate PET, thanks to the complementary information the two metabolic tracers can give $[63,64]$.

\section{Proliferation}

\section{(18F-FLT)}

Introduced in 1998, 18F-fluorothymidine (18F-FLT) [65] is utilised in oncology as a marker of cellular proliferation. More precisely, 18F-FLT is entrapped in cells during the Sphase and its uptake correlates with the activity of thymidine kinase-1 (TK-1), a key enzyme that is up-regulated during DNA synthesis and cellular growth $[65,66]$.

The first attempts made to estimate proliferation activity in cells started almost three decades ago with $11 \mathrm{C}$ thymidine, but $18 \mathrm{~F}-\mathrm{FLT}$, which is derived from the cytostatic drug zidovudine [65, 67], seems to be the most suitable tracer for PET imaging.

In oncology FLT-PET is used for several malignancies, such as lung, oesophageal, gastric and pancreatic tumours, gliomas, sarcomas and lymphomas [68-71], and its uptake in tumour cells is documented to directly correlate with $\mathrm{Ki}$ 67 immunohistochemistry [71].

Fig. 6 Transaxial images of a patient affected by recurrent hepatocarcinoma in the paracaval region (arrow): (a) CeCT; (b) 11C-acetate PET images; (c) fused PET/CT images; (d) localisation $\mathrm{CT}$
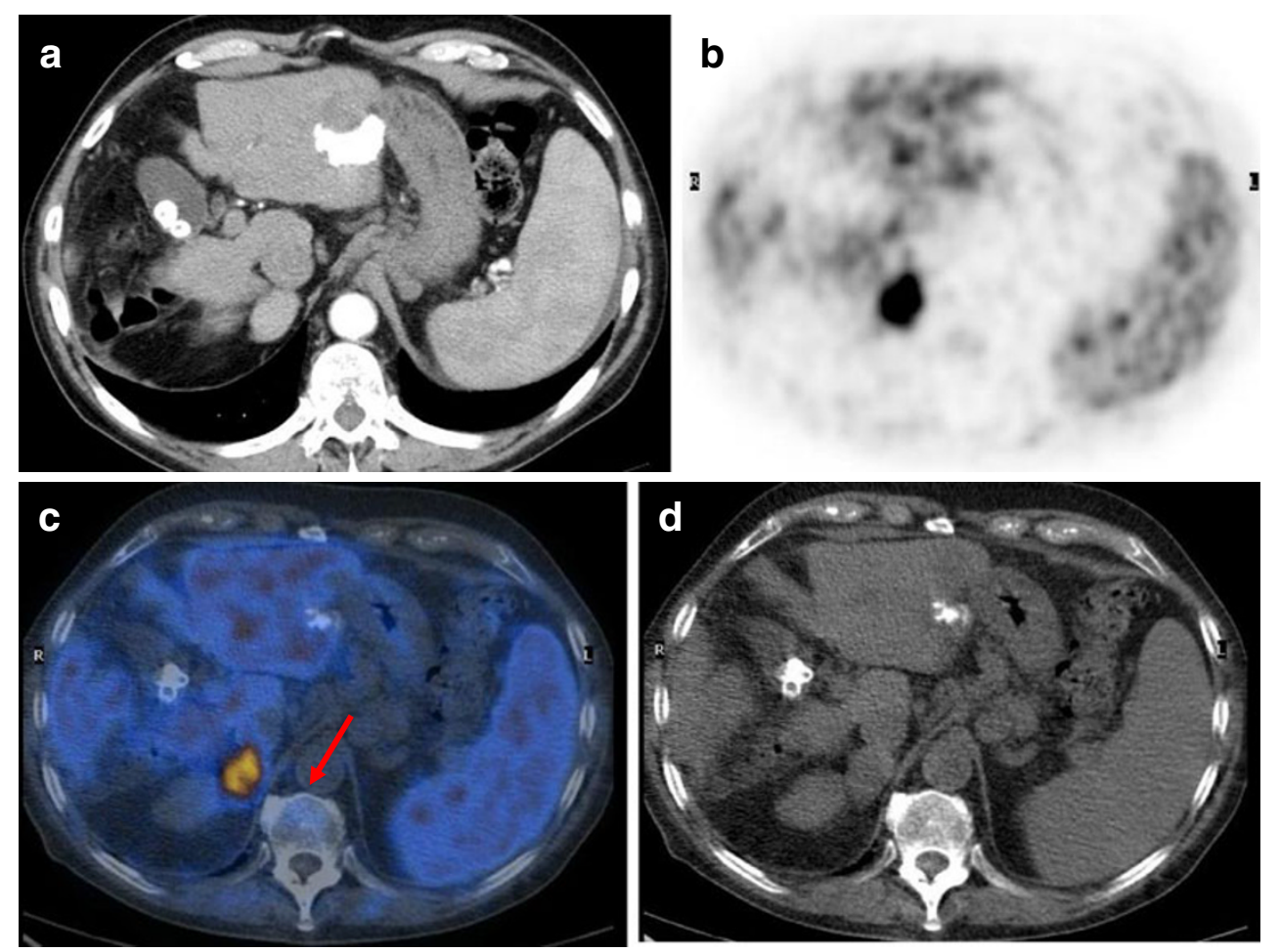
FLT-PET has a good signal-to-background rate, but the tracer is physiologically taken up in bone marrow and hepatic parenchyma, making these tissues difficult to investigate with 18F-FLT [67].

Compared with 18F-FDG uptake, 18F-FLT on average shows a lower accumulation in malignant tissue [68] and the method itself appears less accurate than FDG-PET for staging and restaging evaluation. However $18 \mathrm{~F}-\mathrm{FLT}$ is a more specific oncological tracer than 18F-FDG and can show a good sensitivity in the detection of primary tumour $[68,72]$. As a marker of tumour cell proliferation, 18F-FLT also appears to be more accurate than 18F-FDG in treatment evaluation, by reflecting directly tumoral biological response [71].

\section{Bone metabolism}

\section{$(18 \mathrm{~F}-\mathrm{NaF})$}

Thanks to the broad availability of $18 \mathrm{~F}$, the extremely simple synthesis of the tracer and the frequent shortage of $99 \mathrm{mTc}$, PET imaging with $18 \mathrm{~F}-\mathrm{Fluoride}(18 \mathrm{~F}-\mathrm{NaF})$ may represent the future of bone imaging. Similar to $99 \mathrm{mTc}-$ radiolabelled diphosphonates, $18 \mathrm{~F}-\mathrm{NaF}$ uptake reflects osteoblastic metabolism, thanks to the physiological incorporation of fluoride in bone matrix as fluoroapatite [73]. However, imaging with $18 \mathrm{~F}-\mathrm{NaF}$ has some major advantages over bone scintigraphy, which are related to a more rapid tracer uptake: images can be available immediately after injection, with better image quality; high image resolution is achieved, especially in hybrid PET/CT acquisitions, thanks to an optimal signal-to-background ratio [74].

In several malignancies, such as prostate cancer, lung and breast tumours, PET with $18 \mathrm{~F}$-fluoride has demonstrated a significantly higher diagnostic accuracy compared with bone scintigraphy $[75,76]$, by reaching maximal rates $(100 \%)$ of sensitivity and specificity versus $92 \%$ and $82 \%$ respectively for 99mTc-MDP scintigraphy [77].

Fluoride-PET shows an elevated sensitivity for both sclerotic and lytic lesions [77, 78], but this high sensitivity rate outlines the principal drawback of the tracer: $18 \mathrm{~F}$ fluoride is not a specific oncological tracer, thus sometimes it can be difficult to differentiate between benign and malignant lesions. However combined morphological and functional imaging, as in hybrid PET/CT systems, and the clever recycling of the tracer cocktails concept [79] may help to overcome potential false-positive findings.

Similar to conventional bone scintigraphy, $18 \mathrm{~F}-\mathrm{NaF}$ can also be utilised in other fields of interest related to benign pathological bone conditions, such as orthopaedic problems [80].

\section{Tumour hypoxia and oxygen metabolism}

(18F-FMISO and other tracers)

Tumour hypoxia and oxygen metabolism represent a major task in oncology, and functional imaging with PET can make a remarkable contribution to patient management and therapeutic decisions. It is well known that tumour response to treatment is significantly related to the level of tumour oxygenation and the quota of hypoxic tissue [81].

The first PET tracer introduced for imaging tumour oxygenation was $18 \mathrm{~F}$-fluoromisonidazole (18F-FMISO) [82]. Initially utilised in nuclear cardiology for imaging myocardial ischaemia, the tracer was subsequently introduced into oncology for imaging several malignancies, such as lung cancer, sarcomas, brain tumours and head and neck cancers $[83,84]$.

The presence of a suboptimal signal-to-background ratio and the lack of 18F-FMISO uptake in necrotic tissue led to the development of further hypoxic tracers. This is the case for 18F-fluoroazomycin arabinozide (18F-FAZA) [85], 18F-fluoronitroimidazole (18F-EF3 and 5) [86, 87] or 64Cu-methylthiosemicarbazone (64Cu-ATSM) [88, 89]. All these tracers give remarkable information on imaging tumour hypoxia, although thanks to an optimal biodistribution and a high signal-to-background ratio, the most promising one seems to be $64 \mathrm{Cu}$-ATSM. This tracer has already demonstrated good prognostic values in different tumours, including lung and cervical cancers [87-89].

\section{Conclusions}

This brief outlook provides only a short overview of nonFDG PET tracers and their use in a clinical setting. The potential list of tracers is continuously increasing in number and new applications can hopefully be introduced. The development of fused imaging, where anatomical and functional data are combined, has given diagnostic imaging "new eyes" for old and new indications.

Thanks to the broader availability of PET imaging, the increasing interest and development of molecular imaging and hybrid technology, the future of diagnostic imaging faces no obstacles but mankind's awareness and common sense.

\section{References}

1. Beyer T, Townsend DW, Brun T et al (2000) A combined PET/CT scanner for clinical oncology. J Nucl Med 41(8):1369-1379

2. Podo F (1999) Tumor phospholipid metabolism. NMR Biomed $12: 413-414$ 
3. Husarik DB, Miralbell R, Dubs M et al (2008) Evaluation of [(18) F]-choline PET/CT for staging and restaging of prostate cancer. Eur J Nucl Med Mol Imaging 35(2):253-263

4. Hara T, Kosada N, Kondo T et al (1997) Imaging of brain tumor, lung cancer, esophageal cancer, colon cancer, prostate cancer and bladder cancer with (C-11)choline. J Nucl Med 38(Suppl):250P

5. Briganti A, Chun FK-H, Salonia A et al (2006) Validation of a nomogram predicting the probability of lymph node invasion among patients undergoing radical prostatectomy and an extended pelvic lymphadenectomy. Eur Urol 49:1019-1027

6. Schiavina R, Scattoni V, Castellucci P et al (2008) 11C-choline positron emission tomography/computerized tomography for preoperative lymph-node staging in intermediate-risk and highrisk prostate cancer: comparison with clinical staging nomograms. Eur Urol 54(2):392-401

7. Farsad M, Schiavina R, Castellucci P et al (2005) Detection and localization of prostate cancer: correlation of $11 \mathrm{C}$-choline PET/CT with histopathologic step-section analysis. J Nucl Med 46 (10):1642-1649

8. Giovacchini G, Picchio M, Coradeschi E et al (2008) [(11)C] choline uptake with PET/CT for the initial diagnosis of prostate cancer: relation to PSA levels, tumour stage and anti-androgenic therapy. Eur J Nucl Med Mol Imaging 35(6):1065-1073

9. Castellucci P, Fuccio C, Fanti S (2010) Influence of trigger PSA and PSA kinetics on 11C-choline PET/CT detection rate in patients with biochemical relapse after radical prostatectomy. J Nucl Med. doi:10.2967/jnumed.109.072322

10. Hara T, Kosaka N, Kishi H (1998) PET imaging of prostate cancer using carbon-11-choline. J Nucl Med 39:990-995

11. De Jong I, Pruim J, Elsinga PH et al (2003) 11C-choline positron emission tomography for the evaluation after treatment of localized prostate cancer. Eur Urol 44:32-38

12. Krause BJ, Souvatzoglou M, Tincel M et al (2008) The detection rate of 11-C choline PET/TC depends on the serum PSA-value in patients with biochemical recurrence of prostate cancer. Eur J Nucl Med Mol Imaging 35:18-23

13. Breeuwsma AJ, Pruim J, Van den Bergh AC et al (2010) Detection of local, regional, and distant recurrence in patients with PSA relapse after external-beam radiotherapy using (11)Ccholine positron emission tomography. Int $\mathrm{J}$ Radiat Oncol Biol Phys 77(1):160-164

14. Giovacchini G, Picchio M, Scattoni V et al (2010) PSA doubling time for prediction of $[(11) \mathrm{C}]$ choline PET/CT findings in prostate cancer patients with biochemical failure after radical prostatectomy. Eur J Nucl Med Mol Imaging 37(6):1106-1116

15. Nanni C, Zamagni E, Cavo M et al (2007) 11C-choline vs. $18 \mathrm{~F}-$ FDG PET/CT in assessing bone involvement in patients with multiple myeloma. World J Surg Oncol 20(5):68

16. Hoffman RM (1984) Altered methionine metabolism, DNA methylation and oncogenic expression in carcinogenesis. Biochem Biophys Acta 738:49-87

17. Derlon JM, Bourdet C, Bustany P et al (1989) [11C]L-methionine uptake in gliomas. Neurosurgery 25:720-728

18. Leskinen-Kallio $S$, Någren $K$, Lehikoinen $P$ et al (1991) Uptake of $11 \mathrm{C}$-methionine in breast cancer studied by PET. An association with the size of S-phase fraction. Br J Cancer 64(6):1121-1124

19. Leskinen-Kallio S, Någren K, Lehikoinen $P$ et al (1992) Carbon11-methionine and PET is an effective method to image head and neck cancer. J Nucl Med 33(5):691-695

20. Huang MC, Shih MH, Chung WY et al (2005) Malignancy of intracerebral lesions evaluated with $11 \mathrm{C}$-methionine-PET. J Clin Neurosci 12:775-780

21. Kim S, Chung JK, Im SH et al (2005) 11C-methionine PET as a prognostic marker in patients with glioma: comparison with $18 \mathrm{~F}$ FDG PET. Eur J Nucl Med Mol Imaging 32:52-59
22. Nariai T, Tanaka Y, Wakimoto $\mathrm{H}$ et al (2005) Usefulness of L[methyl-11C] methionine-positron emission tomography as a biological monitoring tool in the treatment of glioma. J Neurosurg 103:498-507

23. Terakawa Y, Tsuyuguchi N, Iwai Y et al (2008) Diagnostic accuracy of $11 \mathrm{C}$-methionine PET for differentiation of recurrent brain tumors from radiation necrosis after radiotherapy. $\mathrm{J}$ Nucl Med 49(5):694-699

24. Chung JK, Kim YK, Kim SK et al (2002) Usefulness of 11Cmethionine PET in the evaluation of brain lesions that are hypo- or isometabolic on 18F-FDG PET. Eur J Nucl Med Mol Imaging 29:176-182

25. Yamane T, Sakamoto S, Senda M (2010) Clinical impact of (11)Cmethionine PET on expected management of patients with brain neoplasm. Eur J Nucl Med Mol Imaging 37(4):685-690

26. Tsuyuguchi N, Takami T, Sunada I et al (2004) Methionine positron emission tomography for differentiation of recurrent brain tumor and radiation necrosis after stereotactic radiosurgery —in malignant glioma. Ann Nucl Med 18(4):291-296

27. Wong TZ, Van der Westhuizen GJ, Coleman RE (2002) Positron emission tomography imaging of brain tumours. Neuroimaging Clin N Am 12:615-626

28. Goldman S, Levivier M, Pirotte B et al (1997) Regional methionine and glucose uptake in high-grade gliomas: a comparative study on PET-guided stereotactic biopsy. J Nucl Med 38:1459-1462

29. Garnett ES, Firnau G, Nahmias C (1983) Dopamine visualized in the basal ganglia of living man. Nature 305:137-138

30. Heiss WD, Wienhard K, Wagner R et al (1996) F-Dopa as an amino acid tracer to detect brain tumours. J Nucl Med 37 (7): $1180-1182$

31. Becherer A, Szabó M, Karanikas G et al (2004) Imaging of advanced neuroendocrine tumors with (18)F-FDOPA PET. J Nucl Med 45(7):1161-1167

32. Hardy O, Hernandez-Pampaloni M, Saffer JR et al (2007) Diagnosis and localization of focal congenital hyperinsulinism by 18F-fluorodopa PET scan. J Pediatr 150(2):140-145

33. Pearce AG (1969) The cytochemistry and ultrastructure of polypeptide hormone-producing cells of the APUD series and the embryologic, physiologic implications of the concept. J Histochem Cytochem 17:303-313

34. Gazdar AF, Helman LJ, Israel MA et al (1988) Expression of neuroendocrine cell markers L-dopa decarboxylase, chromogranin $\mathrm{A}$, and dense core granules in human tumors of endocrine and nonendocrine origin. Cancer Res 48:4078-4082

35. Hoegerle S, Altehoefer C, Ghanem N et al (2001) 18F-DOPA positron emission tomography for tumour detection in patients with medullary thyroid carcinoma and elevated calcitonin levels. Eur J Nucl Med 28(1):64-71

36. Imani F, Agopian VG, Auerbach MS et al (2009) 18F-FDOPA PET and PET/CT accurately localize pheochromocytomas. J Nucl Med 50(4):513-519

37. Koopmans KP, de Vries EG, Kema IP et al (2006) Staging of carcinoid tumours with $18 \mathrm{~F}-\mathrm{DOPA}$ PET: a prospective, diagnostic accuracy study. Lancet Oncol 7(9):728-734

38. Fiebrich HB, Brouwers AH, Kerstens MN et al (2009) 6-[F-18] Fluoro-L-dihydroxyphenylalanine positron emission tomography is superior to conventional imaging with (123)I-metaiodobenzylguanidine scintigraphy, computer tomography, and magnetic resonance imaging in localizing tumors causing catecholamine excess. J Clin Endocrinol Metab 94(10):3922-3930

39. Bombardieri E, Maccauro M, De Deckere E et al (2001) Nuclear medicine imaging of neuroendocrine tumours. Ann Oncol 12 (Suppl 2):S51-S61

40. Kwekkeboom DJ, Kooj PP, Bakker WH et al (1999) Comparison of 111In-DOTA-Tyr3-octreotide and 111In-DTPA-octreotide in 
the same patients: biodistribution, kinetics, organ and tumour uptake. J Nucl Med 40:762-767

41. Hofmann M, Maecke H, Börner R et al (2001) Biokinetics and imaging with the somatostatin receptor PET radioligand $68 \mathrm{Ga}-$ DOTATOC: preliminary data. Eur J Nucl Med 28:1751-1757

42. Prasad V, Baum RP (2010) Biodistribution of the Ga-68 labeled somatostatin analogue DOTA-NOC in patients with neuroendocrine tumors: characterization of uptake in normal organs and tumor lesions. Q J Nucl Med Mol Imaging 54(1):61-67

43. Maecke HR, Hofmann M, Haberkorn U (2005) 68 Ga-labeled peptides in tumor imaging. J Nucl Med 46:172S-178S

44. Baum RP (2005) Receptor PET/CT imaging of neuroendocrine tumors using the Ga-68 labelled, high affinity somatostatin analogue DOTA-1-NaI3-octreotide (DOTA-NOC): clinical results in 327 patients. Eur J Nucl Med Mol Imaging 32:109s

45. Prasad V, Ambrosini V, Hommann M et al (2010) Detection of unknown primary neuroendocrine tumours (CUP-NET) using (68) Ga-DOTA-NOC receptor PET/CT. Eur J Nucl Med Mol Imaging 37:67-77

46. Gabriel M, Decristoforo C, Kendler D et al (2007) 68Ga-DOTATyr3-octreotide PET in neuroendocrine tumours: comparison with somatostatin receptor scintigraphy and CT. J Nucl Med 48:508518

47. Ambrosini V, Nanni C, Zompatori M et al (2010) 68Ga-DOTANOC PET/CT in comparison with CT for the detection of bone metastasis in patients with neuroendocrine tumours. Eur J Nucl Med Mol Imaging 37:722-727

48. Haug A, Auernhammer CJ, Wängler B et al (2009) Intraindividual comparison of [68Ga]DOTA-TATE and [18F]DOPA PET in patients with well-differentiated metastatic neuroendocrine tumours. Eur J Nucl Med Mol Imaging 36:765-770

49. Ambrosini V, Tomassetti P, Castellucci P et al (2008) Comparison between $68 \mathrm{Ga}-\mathrm{DOTA}-\mathrm{NOC}$ and 18F-DOPA PET for the detection of gastro-entero-pancreatic and lung neuro-endocrine tumours. Eur J Nucl Med Mol Imaging 35(8):1431-1438

50. Campana D, Ambrosini V, Pezzilli R et al (2010) Standardized uptake values of (68)Ga-DOTANOC PET: a promising prognostic tool in neuroendocrine tumors. J Nucl Med 51:353-359

51. Gabriel M, Andergassen U, Putzer D et al (2010) Individualized peptide-related-radionuclide-therapy concept using different radiolabelled somatostatin analogs in advanced cancer patients. Q J Nucl Med Mol Imaging 54(1):92-99

52. Howard BV, Howard WJ (1975) Lipids in normal and tumor cells in culture. Prog Biochem Pharmacol 10:135-166

53. Luong A, Hannah VC, Brown MS et al (2000) Molecular characterization of human acetyl-CoA synthetase, an enzyme regulated by sterol regulatory element-binding proteins. J Biol Chem 275(34):26458-26466

54. Rigo P, De Landsheere C, Melon P et al (1990) Imaging of myocardial metabolism by positron emission tomography. Cardiovasc Drugs Ther 4(Suppl 4):847-851

55. Oyama N, Miller TR, Dehdashti F et al (2003) 11C-acetate PET imaging of prostate cancer: detection of recurrent disease at PSA relapse. J Nucl Med 44(4):549-555

56. Ho CL, Yu SC, Yeung DW (2003) 11C-acetate PET imaging in hepatocellular carcinoma and other liver masses. J Nucl Med 44:213-221

57. Liu RS (2000) Clinical application of (C-11)acetate in oncology. Clin Positron Imaging 3(4):185

58. Swinnen JV, Van Veldhoven PP, Timmermans L et al (2003) Fatty acid synthase drives the synthesis of phospholipids partitioning into detergent-resistant membrane microdomains. Biochem Biophys Res Commun 302:898-903

59. Nanni C, Castellucci P, Farsad M et al (2007) 11C/18F-choline PET or $11 \mathrm{C} / 8 \mathrm{~F}$-acetate PET in prostate cancer: may a choice be recommended? Eur J Nucl Med Mol Imaging 34:1704-1705
60. Chierichetti F, Lessi G, Bissoli S et al (2005) Preliminary experience with $11 \mathrm{C}$-acetate and PET7CT in prostate cancer. J Nucl Med 46 (Suppl 2)

61. Soloviev D, Fini A, Chierichetti F et al (2008) PET imaging with $11 \mathrm{C}$-acetate in prostate cancer: a biochemical, radiochemical and clinical perspective. Eur J Nucl Med Mol Imaging 35(5):942-949

62. Albrecht S, Buchegger F, Soloviev D et al (2007) (11)C-Acetate PET in the early evaluation of prostate cancer recurrence. Eur J Nucl Med Mol Imaging 34:185-196

63. Iwata Y, Shiomi S, Sasaki N et al (2000) Clinical usefulness of positron emission tomography with fluorine-18fluorodeoxyglucose in the diagnosis of liver tumors. Ann Nucl Med 14:121-126

64. Hwang KH, Choi DJ, Lee SY et al (2009) Evaluation of patients with hepatocellular carcinomas using [(11)C]acetate and [(18)F]FDG PET/CT: a preliminary study. Appl Radiat Isot 67(7-8):1195-1198

65. Shields AF, Grierson JR, Dohmen BM et al (1998) Imaging proliferation in vivo with $\left[{ }^{18} \mathrm{~F}\right] \mathrm{FLT}$ and positron emission tomography. Nat Med 4:1334-1336

66. Barthel H, Perumal M, Latigo J et al (2005) The uptake of 3'deoxy-3'-[18F]fluorothymidine into L178Y tumours in vivo is dependent on thymidine kinase 1 protein levels. Eur J Nucl Med Mol Imaging 32(3):257-263

67. Shields AF (2006) Positron emission tomography measurement of tumor metabolism and growth: its expanding role in oncology. Mol Imaging Biol 8:141-150

68. Buck AK, Schirrmeister H, Hetzel M et al (2002) 3-Deoxy-3- $\left[{ }^{18} \mathrm{~F}\right]$ fluorothymidine-positron emission tomography for noninvasive assessment of proliferation in pulmonary nodules. Cancer Res 62:3331-3334

69. Buck AK, Herrmann K, Buschenfelde CM et al (2008) Imaging bone and soft tissue tumors with the proliferation marker [18F] fluorothymidine. Clin Cancer Res 14(10):2970-2977

70. Chen W, Cloughesy T, Kamdar N et al (2005) Imaging proliferation in brain tumors with 18F-FLT PET: comparison with 18F-FDG. J Nucl Med 46(6):945-952

71. Yue J, Chen L, Cabrera AR et al (2010) Measuring tumor cell proliferation with $18 \mathrm{~F}$-FLT PET during radiotherapy of esophageal squamous cell carcinoma: a pilot clinical study. J Nucl Med 51(4):528-534

72. Francis DL, Visvikis D, Costa DC et al (2003) Potential impact of [18F]3'-deoxy-3'-fluorothymidine versus [18F]fluoro-2-deoxy-Dglucose in positron emission tomography for colorectal cancer. Eur J Nucl Med Mol Imaging 30(7):988-994

73. Blau M, Nagler W, Bender MA (1962) A new isotope for bone scanning. J Nucl Med 3:332-334

74. Vallabhajosula S (2007) 18F-labeled positron emission tomographic radiopharmaceuticals in oncology: an overview of radiochemistry and mechanisms of tumor localization. Semin Nucl Med 37:400-419

75. Hetzel M, Arslandemir C, Konig HH et al (2003) F-18 NaF PET for detection of bone metastases in lung cancer: accuracy, costeffectiveness, and impact on patient management. J Bone Miner Res 18:2206-2214

76. Even-Sapir E, Metser U, Mishani E et al (2006) The detection of bone metastases in patients with high-risk prostate cancer: $99 \mathrm{mTc}$ MDP planar bone scintigraphy, single- and multi-field-of-view SPECT, 18F-fluoride PET, and 18F-fluoride PET/CT. J Nucl Med 47:287-297

77. Groves AM, Win Th, Ben Haim S et al (2007) Non- $\left[{ }^{18} F\right] F D G$ PET in clinical oncology. Lancet Oncol 8:822-830

78. Even-Sapir E, Metser U, Flusser G et al (2004) Assessment of malignant skeletal disease with $18 \mathrm{~F}$-fluoride PET/CT. J Nucl Med 45:272-278

79. Iagaru A, Mittra E, Yaghoubi SS et al (2009) Novel strategy for cocktail $18 \mathrm{~F}$-flouride and 18F-FDG PET/CT scan for evaluation 
of malignancy: results of a pilot-phase study. J Nucl Med 50:501505

80. Fischer DR, Maquieira GJ, Espinosa N et al (2010) Therapeutic impact of [(18)F]fluoride positron-emission tomography/computed tomography on patients with unclear foot pain. Skeletal Radiol 39(10):987-997

81. Lewis JS, Welch MJ (2001) PET imaging of hypoxia. Q J Nucl Med 45(2):183-188

82. Rasey JS, Grunbaum Z, Magee S et al (1987) Characterization of radiolabeled fluoromisonidazole as a probe for hypoxic cells. Radiat Res 111:292-304

83. Hicks RJ, Rischin D, Fisher R et al (2005) Utility of FMISO PET in advanced head and neck cancer treated with chemoradiation incorporating a hypoxia-targeting chemotherapy agent. Eur J Nucl Med Mol Imaging 32:1384-1391

84. Rajendran JG, Wilson DC, Conrad EU et al (2003) (18)F]FMISO and [(18)F]FDG PET imaging in soft tissue sarcomas: correlation of hypoxia, metabolism and VEGF expression. Eur J Nucl Med Mol Imaging 30:695-704

85. Piert M, Machulla HJ, Picchio M et al (2005) Hypoxia-specific tumor imaging with $18 \mathrm{~F}$-fluoroazomycin arabinoside. J Nucl Med 46:106-113

86. Komar G, Seppaenen M, Eskola O et al (2008) 18F-EF5: a new PET tracer for imaging hypoxia in head and neck cancer. J Nucl Med 49:1944-1951

87. Padhani A (2006) PET imaging of tumour hypoxia. Cancer Imaging 6:S117-S121

88. Dehdashti F, Grigsby PW, Mintun MA et al (2003) Assessing tumor hypoxia in cervical cancer by positron emission tomography with 60Cu-ATSM: relationship to therapeutic response-a preliminary report. Int J Radiat Oncol Biol Phys 55:1233-1238

89. Dehdashti F, Mintun MA, Lewis JS et al (2003) In vivo assessment of tumor hypoxia in lung cancer with $60 \mathrm{Cu}-\mathrm{ATSM}$. Eur J Nucl Med Mol Imaging 30:844-850 